\title{
Impact of Sub-Economic on Money Supply in Nigeria: An Autoregressive Distribution Lag (ARDL) Approach
}

\author{
Yasin Abdelhaleem Yasin Abuhabel, Samuel Olayemi Olanrewaju \\ Department of Statistics, University of Abuja, Abuja, Nigeria \\ Email: olanrewaju.samuel@uniabuja.edu.ng
}

How to cite this paper: Abuhabel, Y.A.Y. and Olanrewaju, S.O. (2020) Impact of Sub-Economic on Money Supply in Nigeria: An Autoregressive Distribution Lag (ARDL) Approach. Open Journal of Statistics, 10, 375-401.

https://doi.org/10.4236/ojs.2020.103025

Received: April 8, 2020

Accepted: May 6, 2020

Published: May 9, 2020

Copyright (อ 2020 by author(s) and Scientific Research Publishing Inc. This work is licensed under the Creative Commons Attribution International License (CC BY 4.0).

http://creativecommons.org/licenses/by/4.0/

\begin{abstract}
The escalation in dollar rates and the price instability in the Nigerian economy went through some significant structural and institutional changes such as the liberalization of the external trade, the elimination of price and interest rate controls, and the adoption of a managed float exchange rate system as well as the changes in monetary policy including innovations in the banking sector. Hence, the study examines the impact of financial development on money demand in Nigeria by means of ARDL approach. It examined the quarterly returns of $\mathrm{M} 2$, exchange rate (EXR), inflation rate (IFR), currency in credits to private sector (CPS) and circulation (CIC). The data span from 1991 to 2018 . The study utilizes regression model techniques where the regression model's residual is tested for Cointegration using Engle-Granger residual approach, the significances of the variable's co-movement are checked by pairwise Granger Causality tests and ARDL and VECM are estimated in order to account for the short run and long run relationship among the variables. From the empirical results, Engle-Granger residuals and pairwise Granger Causality tests confirm cointegration among variables. The ARDL and VECM confirm the long run relation between money demand (M2) and financial development variables: CPS and CIC. ARDL models (short run relationship) are estimated for exchange rate and inflation rate. Long run (VECM) analysis has confirmed significance of financial development variables (CPS and CIC) with positive sign; implies that money demand function is stable in long run. The VECM granger causality results reveal that bidirectional causality exists between currency in circulation and money demand in both short and long run. Unidirectional causal relationship exists between credits to private sector and money demand in both short and long run. Hence, government should pay more attention on financial development and ensure a coordination of both fiscal and monetary policy.
\end{abstract}




\section{Keywords}

Sub-Economy, Money Supply, ARDL, Cointegration, Error Correction Model

\section{Introduction}

The demand for money refers to the total amount of riches held by the households and companies; this is affected by several factors such as income levels, interest rates, price levels (inflation) and uncertainty. The impact of these factors on demand for money can be attributed to these three reasons: transaction, precautionary and speculative. The demand for money function creates a contextual to review the efficacy of monetary policies, as an imperative issue in terms of the overall macroeconomic stability. Money demand is an important indicator or pointer of growth for a particular economy. [1] affirmed that increment in money demand mostly indicates a country's improved economic situation, as against the falling demand which is normally a sign of abating economic climate. Monetarists accentuate the role of governments in controlling for the amount of money in circulation. Their assessment on monetary economics is that the variation on money supply has a major influence on national product in the short run and on price level in the long run. As well, they claim that the objectives of monetary policy are paramountly met by steering the increment rate of money supply.

Today's monetarism is allied with the work of Friedman, who was one among the generation of economists to agree to take Keynesian economics and then disparage it on its own terms. Friedman debated that inflation is at all times and universally a monetary phenomenon. Similarly, he backed that central bank policy aimed at keeping the supply and demand for money in equilibrium, as measured by growth in productivity and demand [2]. For instance, the European Central Bank formally bases its monetary policy on money supply goals. Adversaries of monetarism, including neo-Keynesians, debated that demand for money is central to supply of money and the money supply is controlled by its Central Bank, for example, Central Bank of Nigeria (CBN) while some conservative economists disputed that demand for money cannot be predicted.

Recently, the rise in Nigeria's exchange rates is being acknowledged as the most imperative threat to the country's economy. The exchange rates instability by the means of uncertainty generated, affects negatively economic decisions of investors, implementing of growth policy, the fight against unemployment and economic convergence [3]. [4] pointed out that the monetary policy has no short-term impact on the price changes. In other words, monetary and fiscal policy tools are less important to control the variations of general price level in Nigeria in the short term. On divergent, some authors remark that the short-run and long run effects of money supply are significant [5] [6] [7].

There are short-term and long-term aspects of money demand. The growing 
production relates to the long-term aspect of money demand or the need for money (transaction demand). This means that the increased issue of money which is consistent with price stability may solely be achieved in the long run if it follows the growth of output. [1] stated that the increased issue of money which is consistent with price stability may solely be achieved in the long run if it follows the growth of output. In the short term, a decreasing rate of money circulation may cause the money demand to rise irrespective of the movements in real production. However, the ongoing increase in money supply, regardless of the trends in production, leads to the stronger inflator pressures. Hence, this study set out to examine the relationship between money supply and other macroeconomic time series.

[8] studied the money demand functions for long run and short run for Nepal using the annual data set of 1975 to 2009. The ARDL modeling to cointegration had used to analysis cointegration. The bounds test shows the exists of long run cointegration relationship among demand for real money balances, real GDP and interest rate in case of both narrow and broad monetary aggregates. Furthermore, the CUSUM and CUSUM SQ test reveals that both the long run narrow and broad money demand functions are unchanging (stable).

[9] queried velocity of money demand function and its relationship with interest rate fluctuations of Pakistan data. The results established stable money demand function via velocity of money, real permanent income per capita, real interest rate, transitory income, and expected inflation. It revealed that money velocity is independent from interest rate. [10] revisited money demand function for Japanese economy. The results showed that instability in money demand due to many changes in monetary policy of Japan. [11] tested the stability of money demand function for Tonga using approaches of LSE Hendry's General to Specific (GETS) and Johansen's Maximum Likelihood (JML). The results projected that there is a stable long run cointegrated relationship that exists between real narrow money, real income and rate of interest.

[12] examined whether financial innovation makes money demands is stable or not in Kenya. They used quarterly data (1998Q4 to 2013Q3) and utilized ARDL bounds test. They found out that in the face of financial innovation, money demand in Kenya is stable. Similarly, an earlier study by [13] examined the effect of financial liberalization on money demand in Uganda based on data (1982Q4 to 1998Q4). He employed Johansen cointegration test and found that M2 and its determinants are cointegrated. Thereafter, he used Chow test to assess the stability of the money demand during the period when a financial reform was implemented in the study. The author found out that the introduction of financial liberalization does not make M2 unstable in Uganda.

[14] measured monetary aggregate using $M 2$, and employed a Johansen test. The study's findings showed that M2 and its determinants are cointegrated. Based on the results from Hansen, CUSUM and CUSUMSQ tests, the author concluded that demand for M2 is stable in Nigeria. [15] used another cointegration technique called ARDL bounds test. The author used quarterly data over the 
period of $1970 \mathrm{Q} 1$ to $2002 \mathrm{Q} 4$. The author measured monetary aggregate using M2 and found it to be cointegrated with its determinants. The study further tested for parameter consistency test using CUSUM and CUSUMSQ tests and the results obtained by [16] are mixed. The result from CUSUM showed that M2 is stable while the finding from CUSUMSQ showed that M2 is unstable.

[16] examined the stability of money demand function a case study of Turkey. Johansen cointegration confirmed the long run cointegration relationship among money demand, income and interest rate. Conflictingly, [17] reexamined the money demand function for Turkey and he found an asymmetric behavior and nonlinearity function. His results projected that the stability of money demand function is influenced by upon stability of inflation for monthly data from 1990 to 2012 .

[18] investigated the money demand function a case study of Nigeria over the period 1970 to 2010. They have established stability of M1 by using Chow breakpoint test, (CUSUM) and (CUSUMSQ) tests by incorporating real income, short term interest rate, real expected exchange rate, expected inflation rate and foreign real interest rate.

Meanwhile, this research feasibly will be of extraordinary importance not only to the scholar as regards the use of statistical tools in the analysis of money demand; drawing conclusion and decision making from available data. It could also contribute to the available proposed literature on the concept of money demand in the scientific communal used by experienced top practitioners all around the world.

\section{Aim and Objectives}

This study aims at providing a comprehensive analysis of money demand while the specific objectives are:

1) To estimate the effect of financial development on money demand.

2) To analyze the relationship between money demand and other macroeconomic variables in Nigeria.

3) To brings to light the short and long run impacts of money demand on inflation and other macroeconomic variables in Nigeria.

\section{Research Methodology}

\subsection{Source of Data}

The nature of this study required the usage of secondary data. Data utilized are quarterly time series and covers a period of 1991 to 2018; they are sourced from Central Bank of Nigeria database. The analyses are carried out using the EViews 9.0 package.

\subsection{Research Methodology}

\subsubsection{Regression Model (Ordinary Least Square Method)}

A priori Expectation: $C>0, \beta_{1}>0, \beta_{2}>0$. 
The ordinary Least Square (OLS) technique will be employed in obtaining the numerical estimates of the coefficients of the equation. The OLS method is chosen because it possesses some optimal properties; its computational procedure is fairly simple and it is also an essential component of most other estimation techniques. The regression model is given as

$$
Y_{i}=\beta_{0}+\beta_{1} X_{i}+\varepsilon_{i}, i=1,2, \cdots, n
$$

where $Y_{i}$ and $X_{i}$ are the dependent and independent in the $i$ th observations respectively. $\beta_{0}$ and $\beta_{1}$ are unknown and are usually obtained by method of Least Square, and $\varepsilon_{i}$ is the error term. The least square estimates in this case are given by simple formulas.

$$
\begin{gathered}
\hat{\beta}_{1}=\frac{\sum x_{i} y_{i}-\frac{1}{n} \sum x_{i} \sum y_{i}}{\sum x_{i}^{2}-\frac{1}{n}\left(\sum x_{i}\right)^{2}} \\
\hat{\beta}_{0}=\bar{y}-\hat{\beta} \bar{x}
\end{gathered}
$$

\subsubsection{Auto-Regressive Distributed Lagged (ARDL) Model}

The autoregressive distributed lag (ARDL) models are the standard ordinary least squares regressions, which include the lags of both the dependent variable and independent variables as regressors (Erdoğdu H. and Çiçek H., 2017). The basic form of an $\operatorname{ARDL}(p, q)$ regression model is given as:

$$
\begin{gathered}
Y_{t}=\beta_{0}+\beta_{1} Y_{t-1}+\cdots+\beta_{p} Y_{t-p}+\alpha_{0} X_{t}+\alpha_{1} X_{t-1}+\cdots+\alpha_{q} X_{t-q}+\varepsilon_{t} \\
Y_{t}=\beta_{0}+\sum_{i=1}^{p} \beta_{i} Y_{t-i}+\sum_{i=0}^{q} \alpha_{i} X_{t-i}+\varepsilon_{t}
\end{gathered}
$$

where $\varepsilon_{t}$ is a disturbance term, the dependent variable is a function of its lagged values, the current and lagged values of other exogenous variables in the model; $p$ lags are used for dependent variable while $q$ lags are for exogenous variables. The bounds testing procedure, developed by [16], requires the estimation of the following equation, which derives the relationship between money supply (M2) and its determinants, exchange rates (EXR), inflation rate (IFR), credit to private sector (CPS) and currency in circulation (CIC) as a conditional autoregressive distributed lag (ARDL):

$$
\begin{aligned}
\Delta \mathrm{LM}_{t}= & \alpha_{0}+\sum_{i=1}^{p} \alpha_{i} \Delta \mathrm{LM}_{t-i}+\sum_{i=1}^{q_{1}} \alpha_{2 i} \Delta \mathrm{EXR}_{t-i}+\sum_{i=1}^{q} \alpha_{3 i} \Delta \mathrm{IFR}_{t-i} \\
& +\sum_{i=1}^{q_{3}} \alpha_{4 i} \Delta \mathrm{CPS}_{t-i}+\sum_{i=1}^{q_{4}} \alpha_{5 i} \Delta \mathrm{CIC}_{t-i}+\beta_{1} \mathrm{LM}_{t-1} \\
& +\beta_{2} \mathrm{EXR}_{t-1}+\beta_{3} \mathrm{IFR}_{t-1}+\beta_{4} \mathrm{CPS}_{t-1}+\beta_{5} \mathrm{CIC}_{t-1}+\varepsilon_{t}
\end{aligned}
$$

where LM2 is the natural log of money supply, $\Delta$ is the first difference operator $p, q_{1}, q_{2}, q_{3}$ and $q_{4}$ are the lag lengths. The null hypothesis in the long-run is $H_{0}: \beta_{1}=\beta_{2}=\beta_{3}=\beta_{4}=\beta_{5}=0$ which implies no cointegration. The computed F-statistic is compared with critical values or $p$-values. If the F-test statistic falls less than the lower bound signifies is no cointegration. If the F-test statistic is greater than the upper bound, it signifies cointegration. Conversely, if the F-statistic lies between both critical values, it signifies inconclusive. 
If a long-run relationship among the variables is established (cointegration presence), then the long-run model(s) is/are estimated using Error Correction Term (ECM) while for short-run relationship (no cointegration) ARDL model(s) is/are estimated. The long-run relationship model is specified in the Equation (3.4):

$$
\begin{aligned}
\Delta \mathrm{LM}_{t}= & \alpha_{0}+\sum_{i=1}^{q} \alpha_{i} \Delta \mathrm{LM}_{t-i}+\sum_{i=1}^{p_{1}} \alpha_{2 i} \Delta \mathrm{EXR}_{t-i}+\sum_{i=1}^{p_{2}} \alpha_{3 i} \Delta \mathrm{IFR}_{t-i} \\
& +\sum_{i=1}^{p_{3}} \alpha_{4 i} \Delta \mathrm{CPS}_{t-i}+\sum_{i=1}^{p_{4}} \alpha_{5 i} \Delta \mathrm{CIC}_{t-i}+\lambda_{6} \mathrm{ECT}_{t-1}+\varepsilon_{t}
\end{aligned}
$$

where $\lambda_{6}$ is the coefficient of the error (or equilibrium) correction term (ECT). A negative and statistically significant error correction term ensures convergence of the dynamics to the long-run equilibrium. The significance of the error correction model provides further confirmation to the co-integration evidence, giving the impression of a long run movement between economic growth and the explanatory variables. Implying that in the incidence of the presence of external shock resulting to disequilibrium of the system, the model can still converge with time to its normal state with a relatively average speed of adjustment of $\lambda_{6} \%$ percent per time.

Conversely, for the short-run relationship model; $\operatorname{ARDL}\left(p, q_{1}, q_{2}, q_{3}, q_{4}\right)$ is stated in Equation (3.5).

$$
\begin{aligned}
\Delta \mathrm{LM}_{t}= & \alpha_{0}+\sum_{i=1}^{q} \alpha_{i} \Delta \mathrm{LM} 2_{t-i}+\sum_{i=1}^{p_{1}} \alpha_{2 i} \Delta \mathrm{EXR}_{t-i}+\sum_{i=1}^{p_{2}} \alpha_{3 i} \Delta \mathrm{IFR}_{t-i} \\
& +\sum_{i=1}^{p_{3}} \alpha_{4 i} \Delta \mathrm{CPS}_{t-i}+\sum_{i=1}^{p_{4}} \alpha_{5 i} \Delta \mathrm{CIC}_{t-i}+\varepsilon_{t}
\end{aligned}
$$

\section{Presentation and Analysis of Data}

\section{Presentation of Data}

The data are quarter and generally covers the period from 1991 to 2018. E-Views 9.0 analysis package is utilized to carry out all the analysis in this study. Table 1 presents the variables descriptions of the time series data considered in this study.

Table 2 displays the descriptive statistics for the data. As observed, M2 has mean, median, maximum and minimum of 7184.08, 2415.83, 27,068.58 and 71.03 respectively for the time period examined. $\mathrm{M} 2$ has standard deviation and Jarque-Bera statistic value of 8150.99 and 16.70 respectively with $p$-value of 0.0002 . EXC has mean, median, maximum and minimum of 119.92, 127.99, 306.21 and 9.52 respectively for the time period examined. EXR also, has standard deviation and Jarque-Bera statistic value of 81.78 and 6.90 respectively with $p$-value of 0.0318. IFR has mean, median, maximum and minimum of 19.15, 12.20, 78.50 and 2.30 respectively for the time period examined. And has standard deviation and Jarque-Bera statistic value of 17.31 and 93.17 respectively with $p$-value of 0.0000 .

Furthermore, CPS has mean, median, maximum and minimum of 7191.80, 2067.16, 22,967.44 and 79.96 respectively for the time period examined. And has standard deviation and Jarque-Bera statistic value of 8110.20 and 14.63 respectively 
Table 1. Variables description.

\begin{tabular}{lcc}
\multicolumn{1}{c}{ Variables } & Code & LogCode \\
\hline 1) M2 & M2 & LM2 \\
2) Exchange Rate & EXR & \\
3) Inflation Rate & IFR & \\
4) Credit to Private Sector & CPS & LCPS \\
5) Currency in Circulation & CIC & LCIC \\
\hline
\end{tabular}

Note: L denotes natural logarithm. Variables are in local currency (Naira).

Table 2. Descriptive statistics.

\begin{tabular}{ccccccccc}
\hline & M2 & LM2 & EXR & IFR & CPS & LCPS & CIC & LCIC \\
\hline Mean & 7184.076 & 7.761371 & 119.9235 & 19.15309 & 7191.795 & 7.725483 & 2691.252 & 6.742552 \\
Median & 2415.827 & 7.787807 & 127.9915 & 12.20000 & 2067.156 & 7.633511 & 987.7407 & 6.894110 \\
Maximum & $27,068.58$ & 10.20613 & 306.2095 & 78.50000 & 22967.44 & 10.04183 & 9839.582 & 9.194169 \\
Minimum & 71.02860 & 4.263083 & 9.452100 & 2.700000 & 79.95892 & 4.381513 & 25.12970 & 3.224050 \\
Std. Dev. & 8150.988 & 1.801879 & 81.78081 & 17.30694 & 8110.204 & 1.814827 & 3004.080 & 1.868675 \\
Skewness & 0.896601 & -0.272455 & 0.604130 & 1.889521 & 0.763109 & -0.166562 & 0.883879 & -0.316737 \\
Kurtosis & 2.397231 & 1.740348 & 3.133710 & 5.496694 & 2.007925 & 1.570417 & 2.492814 & 1.695253 \\
Jarque-Bera & 16.70156 & 8.790370 & 6.896261 & 93.17067 & 14.63488 & 9.516501 & 15.78363 & 9.817049 \\
Probability & 0.000236 & 0.012337 & 0.031805 & 0.000000 & 0.000664 & 0.008581 & 0.000374 & 0.007383 \\
Observations & 112 & 112 & 112 & 109 & 112 & 112 & 112 & 112 \\
\hline
\end{tabular}

with $p$-value of 0.0006 . Also, CIC has mean, median, maximum and minimum of $2691.25,987.74,9839.58$ and 25.13 respectively for the time period examined. Its standard deviation and Jarque-Bera statistic value are 0.8839 and 15.73 respectively with $p$-value of 0.0004 . However, M2, CPS and CIC data are converted into natural logarithm in order to stabilize the variance.

From the descriptive statistics results and considering the $p$-values of the variables, this can be deduced; the $p$-values confirm abnormality for all the variables at $1 \%$ level of significance. Figure 1 and Figure 2 present the time series plots of the series.

In Figure 1, it shows that LM2 has been gradually increasing over the years. EXR was relatively constant from 1991 to 1998 but rose abruptly in 1999 and maintained a steady increment from 2000 to 2014 and skyrocketed in 2015 and 2016. IFR also increased gradually over the years; 1991 to 1996 but declined abruptly in 1997 and oscillated over the period 1998 to 2016. LCPS and LCIC have been on gradual increment over the years (see Figure 1).

The plots also show that all the series exhibit non-stationary behaviour. The augmented Dickey Fuller test is used to formally test for stationarity in the time-series.

1) Test for Stationarity 
LM2

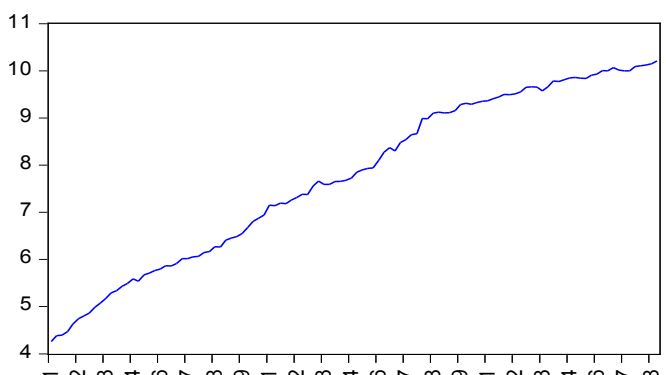

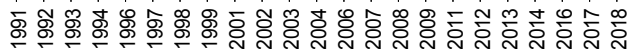

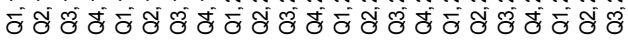

IFR

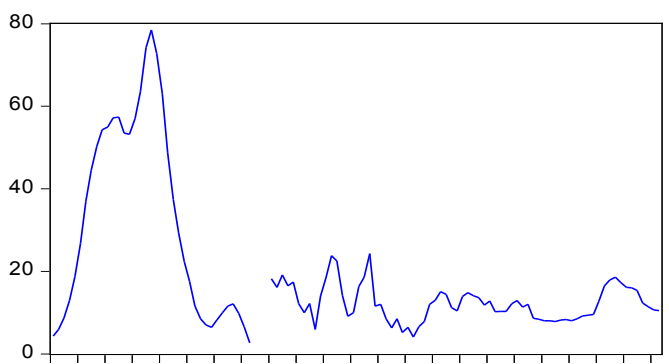

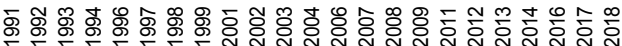

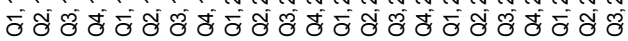

EXR

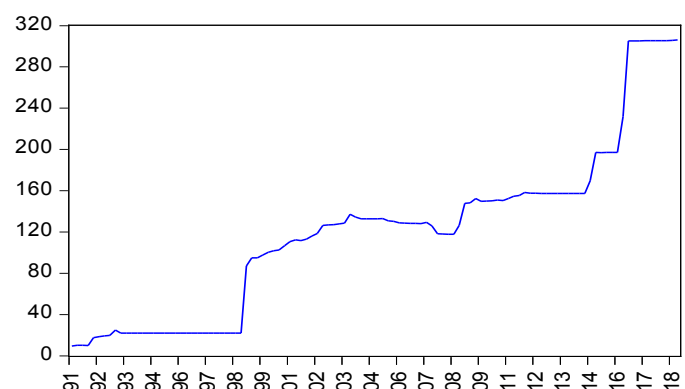

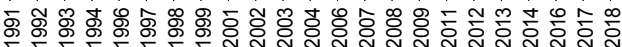

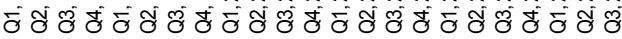

LCPS

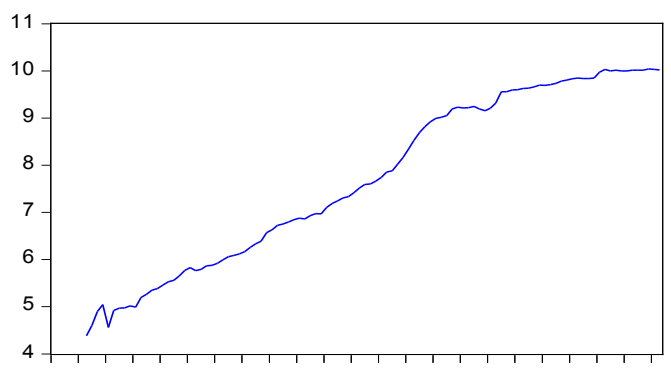

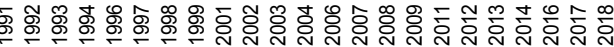

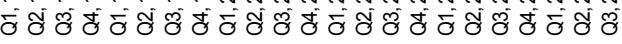
LCIC

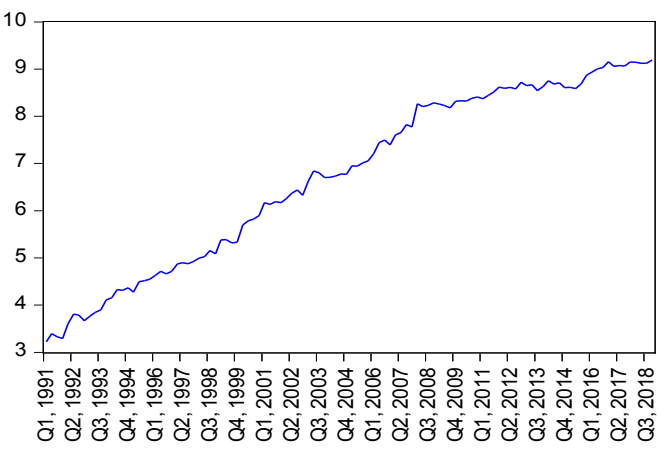

Figure 1. Time series plots.

The results from the ADF test with a linear time trend are reported in Table 3. Using the ADF test, the unit root cannot be rejected for all the four variables at $5 \%$ level of significance which conforms to the time series plots earlier presented. The ADF test with trend is further used at the 1st difference, the unit root can be rejected for all the five (5) variables at $5 \%$ level of significance. Figure 2 presents the stationary series of the variable at first difference. Also, it can be deduced and established that ARDL model is appropriate since data are stationary purely at first difference.

\section{2) Regression Model (Ordinary Least Square Method)}

We made use of the econometric procedure to estimate the relationship between the variables. The ordinary Least Square (OLS) technique is employed to obtain the numerical estimates of the coefficients of the equation. The OLS method is chosen because it possesses some optimal properties; its computational 
DIM2

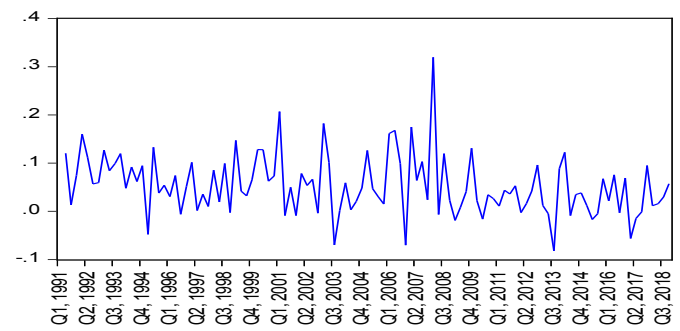

DIFR

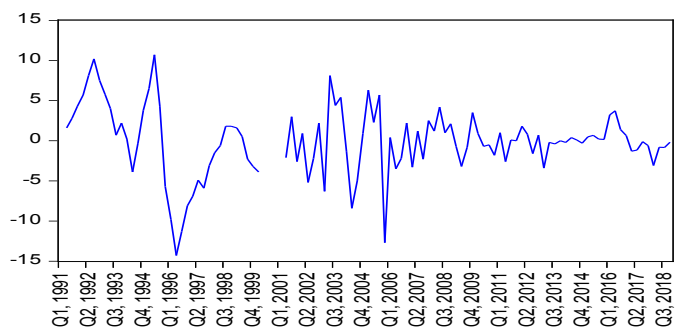

DEXR

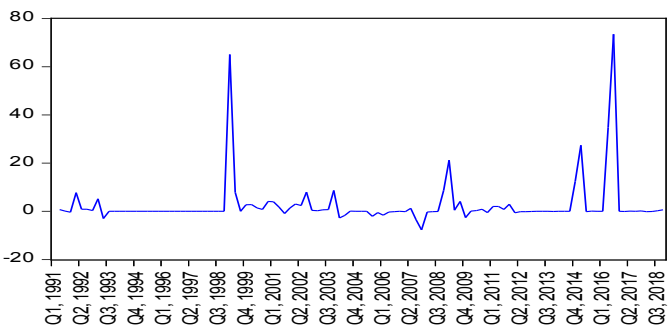
DLCPS

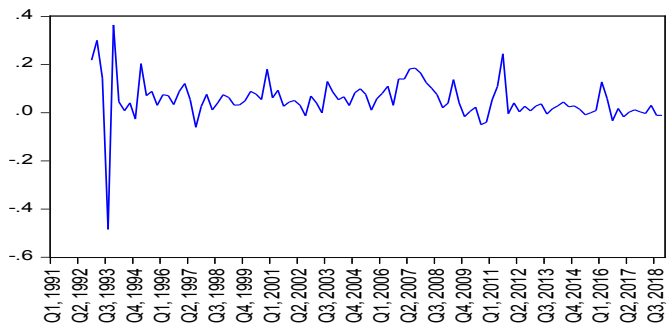

DLCIC

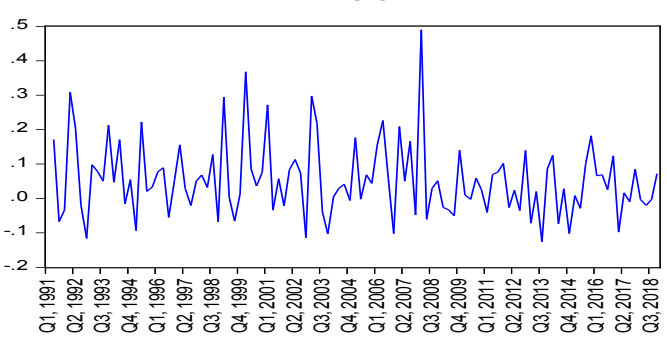

Figure 2. Plots of the differenced time series.

Table 3. Unit root test (ADF test).

\begin{tabular}{ccccc}
\hline Variables & $\mathrm{k}$ & Integration Order $(I)$ & Test Stat & $P$-Value \\
\hline LM2 & 3 & 1 & -4.2519 & 0.0000 \\
EXR & 0 & 1 & -3.5434 & 0.0455 \\
IFR & 4 & 1 & -3.5434 & 0.0455 \\
LCPS & 1 & 1 & -8.5813 & 0.0000 \\
LCIC & 3 & 1 & -5.0763 & 0.0003 \\
\hline
\end{tabular}

Note: $\hat{k}$ is the AIC lag term is used to select the optimal lag, to make the residuals white noise.

procedure is fairly simple and it is also an essential component of most other estimation techniques.

$$
\mathrm{LM} 2=0.0005 \mathrm{EXR}+0.0001 \mathrm{IFR}+0.3997 \mathrm{LCPS}+0.5219 \mathrm{LCIC}+1.1732
$$

The regression estimation results (Table 4) show that the relationship between the dependent LM2 and independent variable EXR, LCPS, LCIC and intercept C, are the significant relationships except for IFR. However, the regression model (4.1) is spurious model since the R-squared is GREATER than the Durbin-Waston statistics (i.e. $0.9987>0.6476$ ). Therefore, the regression model's residual is tested for Cointegration using Engle-Granger residual approach (see Table 5). 
Table 4. Regression model estimation.

\begin{tabular}{ccccc}
\hline \multicolumn{5}{c}{ Dependent Variable: LM2 } \\
\hline Variable & Coefficient & \multicolumn{1}{l}{ Std. Error } & t-Statistic & \multicolumn{1}{c}{ Prob. } \\
\hline EXR & 0.000530 & 0.000160 & 3.303156 & 0.0013 \\
IFR & 0.000105 & 0.000478 & 0.220573 & 0.8259 \\
LCPS & 0.399658 & 0.029601 & 13.50133 & 0.0000 \\
LCIC & 0.521931 & 0.033425 & 15.61503 & 0.0000 \\
C & 1.173199 & 0.048804 & 24.03905 & 0.0000 \\
R-squared & 0.998743 & Mean dependent var & 7.978278 \\
Adjusted R-squared & 0.998692 & S.D. dependent var & 1.681740 \\
S.E. of regression & 0.060826 & Akaike info criterion & -2.714265 \\
Sum squared resid & 0.362584 & Schwarz criterion & -2.586365 \\
Log likelihood & 144.7846 & Hannan-Quinn criter. & -2.662461 \\
F-statistic & 19468.38 & Durbin-Watson stat & 0.647611 \\
Prob (F-statistic) & 0.000000 & & \\
\hline
\end{tabular}

Table 5. Engle granger residual cointegration test.

\begin{tabular}{ccccc}
\hline \multicolumn{2}{l}{$\begin{array}{l}\text { Null hypothesis: Series are not cointegrated } \\
\text { Automatic lags specification based on Akaike criterion (maxlag = 12) }\end{array}$} & \\
\hline Dependent & tau-statistic & Prob. $^{*}$ & $z$-statistic & Prob. $^{*}$ \\
\hline LM2 & -4.820635 & 0.0589 & -43.46458 & 0.0178 \\
EXR & -4.935277 & 0.0453 & -47.48814 & 0.0075 \\
IFR & -5.590841 & 0.0103 & 19.36761 & 1.0000 \\
LCPS & -3.552120 & 0.4853 & -43.38370 & 0.0167 \\
LCIC & -4.902115 & 0.0490 & -47.82295 & 0.0070 \\
\hline
\end{tabular}

\section{3) Cointegration Test}

Table 5 presents the Cointegration test results of the regression model (4.1) residual. The results show that series; LM2, EXR, LCPS and LCIC $p$-values are significant (less than $1 \%$ ), therefore we can reject the $\mathrm{H}_{0}$ in favor of cointegration for all the series except IFR with $p$-value of 1.0000. Hence, the results affirm the presence of Cointegration (variables co-move) among the variables; LM2, EXR, LCPS and LCIC.

Moreover, as results of the presence of Cointegration among the variables (see Table 5), it is crucial to know the nature or significance of the variables' comovement. The pairwise Granger Causality tests were carried out; Table 6 presents the tests' results. Table 6 depicts that the pairwise Granger Causality test is significant for four pairs of the variables considered. As observed, LCPS does granger cause LM2, LM2 does granger cause LCPS, LCIC does granger cause LCPS and LCPS does granger cause LCIC significant at 1\%, 10\%, 10\% and 
Table 6. Pairwise granger causality tests.

\begin{tabular}{|c|c|c|c|}
\hline Null Hypothesis: & Obs & F-Statistic & Prob. \\
\hline DEXR does not Granger Cause DLM2 & 104 & 0.73932 & 0.6392 \\
\hline DLM2 does not Granger Cause DEXR & & 0.74356 & 0.6357 \\
\hline DIFR does not Granger Cause DLM2 & 93 & 0.34742 & 0.9293 \\
\hline DLM2 does not Granger Cause DIFR & & 0.53150 & 0.8081 \\
\hline DLCPS does not Granger Cause DLM2 & 98 & 3.39285 & $0.0031^{* * *}$ \\
\hline DLM2 does not Granger Cause DLCPS & & 2.01479 & $0.0627^{\star}$ \\
\hline DLCIC does not Granger Cause DLM2 & 104 & 0.64457 & 0.7179 \\
\hline DLM2 does not Granger Cause DLCIC & & 0.74048 & 0.6383 \\
\hline DIFR does not Granger Cause DEXR & 93 & 0.58817 & 0.7636 \\
\hline DEXR does not Granger Cause DIFR & & 0.23828 & 0.9745 \\
\hline DLCPS does not Granger Cause DEXR & 98 & 0.49339 & 0.8369 \\
\hline DEXR does not Granger Cause DLCPS & & 1.02445 & 0.4204 \\
\hline DLCIC does not Granger Cause DEXR & 104 & 1.25640 & 0.2812 \\
\hline DEXR does not Granger Cause DLCIC & & 0.61696 & 0.7406 \\
\hline DLCPS does not Granger Cause DIFR & 87 & 0.16236 & 0.9917 \\
\hline DIFR does not Granger Cause DLCPS & & 0.30927 & 0.9476 \\
\hline DLCIC does not Granger Cause DIFR & 93 & 0.86412 & 0.5386 \\
\hline DIFR does not Granger Cause DLCIC & & 0.10017 & 0.9982 \\
\hline DLCIC does not Granger Cause DLCPS & 98 & 1.92986 & $0.0750^{*}$ \\
\hline DLCPS does not Granger Cause DLCIC & & 2.34580 & $0.0309^{* *}$ \\
\hline
\end{tabular}

Note: ${ }^{*},{ }^{* *}$ and ${ }^{* * *}$ denote significant at $10 \%, 5 \%$ and $1 \%$ respectively.

respectively. However, EXR and IFR show no significant granger causes for any variables. Thus, subsequent analysis depicts the cointegration models (ARDL and VECM) of the variables.

\section{4) Autoregressive Distribution Lags Estimation}

Table 7 presents the Bound test results of the ARDL models. The results show that EXR and IFR as dependent variable do not exhibit long-run relationship (no Cointegration) with their corresponding exogenous variables. Thus, the null hypothesis for the long-run relationship can be rejected for only the number 1, 4 and 5 ARDL models (LM2, LCPS and LCIC as dependent variable). The ARDL models (short-run relationship) for EXR and IFR are specified (see model 4.2, and 4.3).

$$
\begin{aligned}
\Delta \mathrm{DEXR}= & 1.2206 \Delta \mathrm{EXR}(-1)-0.2631 \Delta \mathrm{EXR}(-2)+14.6556 \Delta \mathrm{LM} 2 \\
& -0.0026 \Delta \mathrm{IFR}-4.3769 \Delta \mathrm{LCPS}-7.3744 \Delta \mathrm{LCIC}-24.2920 \\
\Delta \mathrm{IFR}= & 1.4176 \Delta \mathrm{IFR}(-1)-0.1883 \Delta \mathrm{IFR}(-2)-0.5156 \Delta \mathrm{IFR}(-3) \\
& +0.2216 \Delta \mathrm{IFR}(-4)-0.5504 \Delta \mathrm{LM} 2+0.0021 \Delta \mathrm{EXR} \\
& +0.6262 \Delta \mathrm{LCPS}-0.5629 \Delta \mathrm{LCIC}+4.2937
\end{aligned}
$$


Table 7. ARDL bound test.

\begin{tabular}{cccccc}
\hline S/N & Dependent Variable & Model Selection & F-Statistic & Cointegration & Decision \\
\hline 1 & LM2 & ARDL $(1,0,0,1,2)$ & $6.7031^{\star}$ & Yes & Estimate ECM (long-run model) \\
2 & EXR & ARDL $(2,0,0,0,0)$ & 0.9120 & No & Estimate ARDL (short-run model) \\
3 & IFR & ARDL $(4,0,0,0,0)$ & 0.8086 & No & Estimate ARDL (short-run model) \\
4 & LCPS & ARDL $(3,0,0,0,0)$ & $5.0812^{\star}$ & Yes & Estimate ECM (long-run model) \\
5 & LCIC & ARDL $(1,1,0,0,1)$ & $4.8416^{\star}$ & Yes & Estimate ECM (long-run model) \\
\hline
\end{tabular}

Note: ${ }^{*}$ indicates significant at 0.05 level (i.e. F-Stat $>4.01$ critical value).

The long-run relationships exhibited by LM2, LCPS and LCIC and exogenous variables are estimated by means of vector error correction model (VECM).

\section{5) Vector Error Correction Model Estimation}

The existence of cointegration between LM2, EXR, IFR, LCPS and LCIC and as the results of the ARDL bound test, they lead us to apply Granger causality test to perform clear picture of causality relationship among these variables. Table 8 presents the cointegration equation and depicts the long run relationship between LM2, EXR, IFR, LCPS and LCIC. The results explain that LCPS and LCIC. Have positively significant impact on LM2. However, EXR and IFR have an insignificant impact on LM2. It means that $1 \%$ increase in LCPS and LCIC will lead to increase in LM2 by $31.15 \%$ and $62.18 \%$ respectively.

The cointegrating equation and long-run model is given by model 4.4 and 4.5:

$$
\begin{aligned}
\mathrm{ECT}_{t-1}= & \mathrm{LM}_{t-1}-0.0001 \mathrm{EXR}_{t-1}-0.0011 \mathrm{IFR}_{t-1} \\
& -0.3115 \mathrm{LCPS}_{t-1}-0.6218 \mathrm{LCIC}_{t-1}-1.1965 \\
\mathrm{LM}_{t-1}= & 0.0001 \mathrm{EXR}_{t-1}+0.0011 \mathrm{IFR}_{t-1}+0.3115 \mathrm{LCPS}_{t-1} \\
& +0.6218 \mathrm{LCIC}_{t-1}+1.197
\end{aligned}
$$

The results of VECM granger causality has reported in Table 9. The path of causality can be divided into short run and long run causality. The results show that LM2 causes LCIC (a financial development variable) in short-run only but LCIC causes LM2 both in short- and long-run. Thus, we can approximately say that bidirectional causality exists between "currency in circulation" and money demand (LM2). Also, LM2 causes LCPS (a financial development variable) both in short and long run while LCPS does not cause LM2 both in short and long run. So, unidirectional causality exists between money demand and "credits to private sectors". Lastly, LCIC cause itself only in both short.

The VECM residual diagnostic test was also applied to the empirical model to measure the adequacy of the specification of the model. As displayed in Table 10, the computed Residual Serial Lagrange multiplier (LM) test for AR[4] = 31.41 is statistically insignificant at conventional significance levels, which suggests that the disturbances are serially uncorrelated.

\section{6) Variance Decomposition Approach}

Variance Decomposition Approach is an improved approach to Granger causality. It signposts the magnitude of projected error variance for a series accounted 
Table 8. Long run analysis.

\begin{tabular}{cc}
\hline Cointegrating Eq: & ECT(-1) \\
\hline $\operatorname{LM} 2(-1)$ & 1.000000 \\
$\operatorname{EXR}(-1)$ & -0.000113 \\
& $(0.00034)$ \\
& {$[-0.32737]$} \\
$\operatorname{IFR}(-1)$ & -0.001102 \\
& $(0.00100)$ \\
$\operatorname{LCPS}(-1)$ & {$[-1.10643]$} \\
& -0.311468 \\
& $(0.06352)$ \\
$\operatorname{LCIC}(-1)$ & {$[-4.90327]^{\mathrm{a}}$} \\
& -0.621778 \\
& $(0.07217)$ \\
& {$[-8.61579]^{\mathrm{a}}$} \\
\hline
\end{tabular}

Note: Standard errors in ( ) \& $t$-statistics in [], ${ }^{\text {a }}$ significant at $1 \%$.

Table 9. VECM granger causality analysis.

\begin{tabular}{|c|c|c|c|c|c|c|c|}
\hline \multirow{2}{*}{$\begin{array}{c}\text { Dependent } \\
\text { Variable }\end{array}$} & \multicolumn{6}{|c|}{ Short-Run } & \multirow{2}{*}{$\begin{array}{l}\text { Long-Run } \\
\text { ECT(-1) }\end{array}$} \\
\hline & $\mathrm{C}$ & $\operatorname{DLCIC}(-1)$ & DLCPS $(-1)$ & $\operatorname{DIFR}(-1)$ & $\operatorname{DEXR}(-1)$ & DLM2(-1) & \\
\hline \multirow{3}{*}{ DLM2 } & 0.043803 & -0.3212 & 0.101315 & -0.000698 & $-9.71 \mathrm{E}-05$ & 0.308855 & -0.2173 \\
\hline & $(0.00896)$ & $(0.1109)$ & $(0.07416)$ & $(0.00144)$ & $(0.00054)$ & $(0.18265)$ & $(0.09862)$ \\
\hline & {$[4.8860]^{\mathrm{a}}$} & {$[-2.8973]^{\mathrm{b}}$} & [1.36613] & {$[-0.48351]$} & {$[-0.1784]$} & [1.69093] & {$[-2.2035]^{\mathrm{b}}$} \\
\hline \multirow{3}{*}{ DLCPS } & 0.042472 & -0.198273 & -0.090789 & 0.000757 & -0.00039 & 0.473076 & -0.03296 \\
\hline & $(0.01371)$ & $(0.16952)$ & $(0.11340)$ & $(0.00221)$ & $(0.00083)$ & (0.17930) & $(0.0080)$ \\
\hline & {$[3.0982]^{\mathrm{a}}$} & {$[-1.16961]$} & {$[-0.80058]$} & {$[0.34278]$} & {$[-0.4672]$} & {$[2.6385]^{\mathrm{b}}$} & {$[-4.1200]^{\mathrm{a}}$} \\
\hline \multirow{3}{*}{ DLCIC } & 0.043393 & -0.416171 & 0.165318 & -0.000895 & -0.00026 & 0.388552 & 0.097993 \\
\hline & $(0.01606)$ & $(0.19857)$ & $(0.13284)$ & $(0.00259)$ & (0.00097) & $(0.1717)$ & $(0.17664)$ \\
\hline & {$[2.7023]^{a}$} & {$[-2.0958]^{\mathrm{b}}$} & {$[1.24450]$} & {$[-0.34617]$} & {$[-0.2631]$} & {$[2.2630]^{\mathrm{b}}$} & {$[0.55475]$} \\
\hline
\end{tabular}

Source: Authors computation. Note: ( ) Standard errors, [] $t$-statistics, ${ }^{a}$ and ${ }^{\mathrm{b}}$ significant at $1 \%$ \& respectively.

Table 10. VEC residual serial correlation LM tests.

\begin{tabular}{ccc}
\hline \multicolumn{2}{l}{$\begin{array}{l}\text { Null Hypothesis: no serial correlation at lag order } h \\
\text { Sample: } 1112 \\
\text { Included observations: } 99\end{array}$} & \\
\hline Lags & LM-Stat & Prob \\
\hline 1 & 26.37222 & 0.3880 \\
2 & 25.29744 & 0.4458 \\
3 & 21.20947 & 0.6809 \\
4 & 31.41266 & 0.1757 \\
\hline
\end{tabular}

Probs from chi-square with $25 \mathrm{df}$. 
for by innovations from the independent variables over different time-horizons. Table 11 has incorporated results of Variance Decomposition Approach (VDA). It presents the forecast error variance in LM2, LCPS and LCIC. The period (1) signifies the short run while down to period (10) it signifies long-run.

Table 11. Variance decomposition approach.

\begin{tabular}{|c|c|c|c|c|c|c|}
\hline \multicolumn{7}{|c|}{ Variance Decomposition of LM2: } \\
\hline Period & S.E. & LM2 & EXR & IFR & LCPS & LCIC \\
\hline 1 & 0.057725 & 100.0000 & 0.000000 & 0.000000 & 0.000000 & 0.000000 \\
\hline 2 & 0.076813 & 95.24680 & 0.150191 & 0.009477 & 2.549037 & 2.044492 \\
\hline 3 & 0.093464 & 93.73310 & 0.171608 & 0.011206 & 4.588927 & 1.495162 \\
\hline 4 & 0.108785 & 91.40150 & 0.177070 & 0.026711 & 7.256403 & 1.138318 \\
\hline 5 & 0.123587 & 88.82029 & 0.176112 & 0.060434 & 9.801132 & 1.142034 \\
\hline 6 & 0.137957 & 86.18641 & 0.173334 & 0.109258 & 12.13253 & 1.398474 \\
\hline 7 & 0.151926 & 83.68921 & 0.169827 & 0.166690 & 14.17727 & 1.797011 \\
\hline 8 & 0.165480 & 81.40647 & 0.166217 & 0.227174 & 15.94317 & 2.256973 \\
\hline 9 & 0.178606 & 79.36427 & 0.162763 & 0.286880 & 17.45635 & 2.729733 \\
\hline 10 & 0.191299 & 77.55782 & 0.159579 & 0.343568 & 18.75106 & 3.187971 \\
\hline \multicolumn{7}{|c|}{ Variance Decomposition of LCPS: } \\
\hline Period & S.E. & LM2 & EXR & IFR & LCPS & LCIC \\
\hline 1 & 0.088269 & 1.309463 & 0.504234 & 0.685781 & 97.50052 & 0.000000 \\
\hline 2 & 0.121403 & 3.129396 & 1.042118 & 1.159614 & 94.11820 & 0.550675 \\
\hline 3 & 0.149967 & 3.339975 & 1.251581 & 1.365604 & 93.45045 & 0.592389 \\
\hline 4 & 0.175195 & 3.546756 & 1.330117 & 1.495353 & 93.15496 & 0.472818 \\
\hline 5 & 0.198460 & 3.669680 & 1.360759 & 1.596008 & 93.00275 & 0.370803 \\
\hline 6 & 0.220154 & 3.763920 & 1.370092 & 1.680355 & 92.88191 & 0.303719 \\
\hline 7 & 0.240577 & 3.835827 & 1.369374 & 1.752676 & 92.77548 & 0.266645 \\
\hline 8 & 0.259914 & 3.893242 & 1.363873 & 1.815263 & 92.67623 & 0.251392 \\
\hline 9 & 0.278301 & 3.939925 & 1.356235 & 1.869660 & 92.58336 & 0.250816 \\
\hline 10 & 0.295846 & 3.978573 & 1.347823 & 1.917093 & 92.49689 & 0.259622 \\
\hline \multicolumn{7}{|c|}{ Variance Decomposition of LCIC: } \\
\hline Period & S.E. & LM2 & EXR & IFR & LCPS & LCIC \\
\hline 1 & 0.103397 & 75.03825 & 0.244132 & 0.445003 & 0.253103 & 24.01951 \\
\hline 2 & 0.131948 & 79.20227 & 0.157836 & 0.499701 & 1.357845 & 18.78235 \\
\hline 3 & 0.156708 & 80.99061 & 0.117007 & 0.610578 & 1.535111 & 16.74670 \\
\hline 4 & 0.178068 & 81.59022 & 0.094788 & 0.699348 & 1.778569 & 15.83707 \\
\hline 5 & 0.197492 & 81.79768 & 0.080296 & 0.757616 & 1.974621 & 15.38979 \\
\hline 6 & 0.215367 & 81.82338 & 0.070282 & 0.793404 & 2.153615 & 15.15932 \\
\hline 7 & 0.232040 & 81.76580 & 0.062935 & 0.814407 & 2.312333 & 15.04452 \\
\hline 8 & 0.247718 & 81.66879 & 0.057333 & 0.826065 & 2.454067 & 14.99374 \\
\hline 9 & 0.262560 & 81.55517 & 0.052927 & 0.831894 & 2.580370 & 14.97964 \\
\hline 10 & 0.276681 & 81.43680 & 0.049376 & 0.834116 & 2.693024 & 14.98668 \\
\hline
\end{tabular}

Cholesky Ordering: LM2 EXR IFR LCPS LCIC. 
According to the VDA results, $77.56 \%$ of LM2 is explaining by itself, $0.16 \%$ of LM2 is explaining by EXR, $0.34 \%$ of LM2 is explained by IFR, $18.75 \%$ of LM2 is explained by LCPS and $3.19 \%$ of LM2 is explained by LCIC. The major portion in explaining LM2 has LCPS. The ratio of LM2, EXR, IFR and LCIC to LCPS is $3.98 \%, 1.35 \%, 1.92 \%$ and $0.26 \%$ respectively. $92.50 \%$ of LCPS is explained by itself. Similarly, $81.44 \%$ of LCIC is explained by LM2, $0.05 \%$ of LCIC is explained by EXR, $0.83 \%$ of LCIC is explained by IFR, $2.69 \%$ of LCIC is explained by LCPS and $14.99 \%$ of LCIC is explained by itself.

\section{Summary}

This research work examined the impact of financial development on money demand in Nigeria by means of ARDL approach. It examined the quarterly returns of M2, exchange rate (EXR), inflation rate (IFR), currency in credits to private sector (CPS) and circulation (CIC). The data span from 1991 to 2018.

In the preliminary analysis, the descriptive statistics and distribution of all the series revealed conventional facts. Also, the time series plots and augmented dickey-fuller tests of the original series indicate non-stationarity thus necessitating appropriate transformation to achieve stationarity.

In successive analysis, the study further employed regression model. The regression model's residual is tested for Cointegration using Engle-Granger residual approach, the significances of the variable's co-movement are checked by pairwise Granger Causality tests and ARDL and VECM are estimated in order to account for the short run and long run relationship among the variables.

\subsection{Conclusions}

The objectives of the study have been basically accomplished. Engle-Granger residuals test and pairwise Granger Causality test have been applied to check cointegration among variables. Both tests have confirmed cointegration among variables. The ARDL and VECM confirm the long-run relation between money demand (M2) and financial development variables; credits to private sector and currency in circulation. ARDL models (short-run relationship) are estimated for exchange rate and inflation rate. Long-run (VECM) analysis has confirmed significance of financial development variables (CPS and CIC) with positive sign (see model 4.5). It means that money demand function is stable in long-run.

VECM Granger causality was applied to check causality in short- and long-run. Results revealed that bidirectional causality exists between currency in circulation and money demand in both short and long run. Unidirectional causal relationship exists between credits to private sector and money demand in both short- and long-run.

\subsection{Recommendations}

From the aforesaid,

1) Government should pay more attention on financial development i.e. cre- 
dits to private sector and currency in circulation, in both short and long run to control money demand since it has statistically significant impact on money demand in both short-run and long-run.

2) We suggest a coordination of both fiscal and monetary policy.

\section{Conflicts of Interest}

The authors declare no conflicts of interest regarding the publication of this paper.

\section{References}

[1] Maravić, J. and Mirjana, P. (2010) Econometric Analysis of Money.

[2] Friedman, M. (1970) A Theoretical Framework for Monetary Analysis. Journal of Political Economy, 78, 193-238. https://doi.org/10.1086/259623

[3] Drama, B.G. and Yao, K.A. (2018) Oil Price, Budget Deficit, Money Supply and Inflation in WAEMU Countries. Asian Journal of Economic Modeling, 6, 317-326.

[4] Keho, Y. (2016) Budget Deficits, Money Supply and Price Level in West Africa. Journal of Economic and Financial Studies, 4, 1-8. https://doi.org/10.18533/jefs.v4i05.209

[5] Doe, L. and Diarisso, S. (1998) The Monetary Origin of Inflation in the WAEMU Countries. Information Notes and Statistics, BCEAO.

[6] Nubukpo, K.K. (2003) The Effectiveness of the Monetary Policy of the Central Bank of West African States Since the Liberalization of 1989. Center for International Cooperation for Agronomic Research and Development (CIRAD), 1-42.

[7] Dembo Toe, M. (2010) Forecast of Inflation in the WAEMU Zone: A Component Approach. BCEAO, Study and Research Paper, No. DER 11/02.

[8] Bhatta, R.S. (2011) Stability of Demand for Money Function in Nepal: A Cointegration and Error Correction Modeling Approach, MPRA Paper No. 41404, University Library of Munich, Munich.

[9] Omer, M. (2010) Stability of Money Demand Function in Pakistan. SPB Working Paper Series.

[10] Tang, C.F. (2007) The Stability of Money Demand Function in Japan: Evidence from Rolling Cointegration Approach. MPRA paper 19807, University Library of Munich, Germany.

[11] Kumar, S. and Manoka, B. (2008) Testing the Stability of Demand for Money in Tonga. MPRA Paper 19300, University Library of Munich, Germany.

[12] Ndirangu, L. and Nyamongo, E.M. (2015) Financial Innovations and Their Implications for Monetary Policy in Kenya. Journal of African Economics, 24, i48-i71. https://doi.org/10.1093/jae/eju029

[13] Nachega, J.-C. (2001) Financial Liberalization, Money Demand and Inflation in Uganda. IMP Working Paper 01/118. https://doi.org/10.5089/9781451854084.001

[14] Anoruo, E. (2002) Stability of the Nigerian M2 Money Demand Function in the SAP Period. Economics Bulletin, 14, 1-9.

[15] Akinlo, E.A. (2006) The Stability of Money Demand in Nigeria: An Autoregressive Distributed Lag Approach. Journal of Policy Modelling, 28, 445-452. https://doi.org/10.1016/j.jpolmod.2005.09.001

[16] Dogru, B. and Recepoglu, M. (2013) Dynamic Analysis Money Demand Function in 
Turkey. International Journal of Economics and Finance, 5, 20.

https://doi.org/10.5539/ijef.v5n9p20

[17] Afsin, S. (2013) Estimating Money Demand Function by a Smooth Transition Regression Model: An Evidence for Turkey. Working Papers 791, Economic Research Forum.

[18] Iyoboyi, M. and Pedro, L.M. (2013) The Demand for Money in Nigeria: Evidence from Bounds Testing Approach. Business and Economics Journal, 2013, BEJ-76. 


\section{Appendix}

Null Hypothesis: LM2 has a unit root

Exogenous: Constant, Linear Trend

Lag Length: 4 (Automatic-based on AIC, maxlag = 4)

\begin{tabular}{cccc}
\hline & & $t$-Statistic & Prob. $^{*}$ \\
\hline Augmented Dickey-Fuller test statistic & -0.647617 & 0.9738 \\
Test critical values: & $1 \%$ level & -4.046072 & \\
& $5 \%$ level & -3.452358 & \\
& & & \\
& $10 \%$ level & -3.151673 &
\end{tabular}

${ }^{\star}$ MacKinnon (1996) one-sided $p$-values.

Null Hypothesis: D (LM2) has a unit root

Exogenous: Constant, Linear Trend

Lag Length: 3 (Automatic-based on AIC, maxlag = 4)

\begin{tabular}{cccc}
\hline & & $t$-Statistic & Prob. $^{*}$ \\
\hline Augmented Dickey-Fuller test statistic & -4.251920 & 0.0053 \\
Test critical values: & $1 \%$ level & -4.046072 & \\
& $5 \%$ level & -3.452358 & \\
& $10 \%$ level & -3.151673 &
\end{tabular}

${ }^{*}$ MacKinnon (1996) one-sided $p$-values.

Null Hypothesis: EXR has a unit root

Exogenous: Constant, Linear Trend

Lag Length: 1 (Automatic—based on AIC, maxlag=4)

\begin{tabular}{cccc}
\hline & & $t$-Statistic & Prob. $^{*}$ \\
\hline Augmented Dickey-Fuller test statistic & -1.963052 & 0.6145 \\
Test critical values: & \% level & -4.043609 & \\
& $5 \%$ level & -3.451184 & \\
& $10 \%$ level & -3.150986 &
\end{tabular}

Null Hypothesis: D(EXR) has a unit root

Exogenous: Constant, Linear Trend

Lag Length: 0 (Automatic-based on AIC, maxlag = 4)

\begin{tabular}{|c|c|c|c|}
\hline & & $t$-Statistic & Prob.* ${ }^{*}$ \\
\hline \multicolumn{2}{|c|}{ Augmented Dickey-Fuller test statistic } & -8.180842 & 0.0000 \\
\hline \multirow[t]{3}{*}{ Test critical values: } & $1 \%$ level & -4.043609 & \\
\hline & $5 \%$ level & -3.451184 & \\
\hline & $10 \%$ level & -3.150986 & \\
\hline
\end{tabular}


Null Hypothesis: IFR has a unit root

Exogenous: Constant, Linear Trend

Lag Length: 3 (Automatic-based on AIC, maxlag = 4)

\begin{tabular}{cccc}
\hline & & $t$-Statistic & Prob. $^{*}$ \\
\hline Augmented Dickey-Fuller test statistic & -2.533017 & 0.3119 \\
Test critical values: & $1 \%$ level & -4.051450 & \\
& $5 \%$ level & -3.454919 & \\
$10 \%$ level & -3.153171 & \\
\hline
\end{tabular}

Null Hypothesis: D (IFR) has a unit root

Exogenous: Constant, Linear Trend

Lag Length: 4 (Automatic-based on AIC, maxlag = 4)

\begin{tabular}{cccc}
\hline & & $t$-Statistic & Prob. $^{*}$ \\
\hline Augmented Dickey-Fuller test statistic & -3.543375 & 0.0455 \\
Test critical values: & $1 \%$ level & -4.055416 & \\
& $5 \%$ level & -3.456805 & \\
& $10 \%$ level & -3.154273 & \\
\hline
\end{tabular}

Null Hypothesis: LCPS has a unit root

Exogenous: Constant, Linear Trend

Lag Length: 4 (Automatic-based on AIC, maxlag = 4)

\begin{tabular}{cccc}
\hline & & $t$-Statistic & Prob. $^{*}$ \\
\hline Augmented Dickey-Fuller test statistic & -0.520437 & 0.9811 \\
Test critical values: & $1 \%$ level & -4.051450 & \\
& $5 \%$ level & -3.454919 & \\
& $10 \%$ level & -3.153171 & \\
\hline
\end{tabular}

Null Hypothesis: D(LCPS) has a unit root

Exogenous: Constant, Linear Trend

Lag Length: 1 (Automatic-based on AIC, maxlag = 4)

\begin{tabular}{cccc}
\hline & & $t$-Statistic & Prob. $^{*}$ \\
\hline Augmented Dickey-Fuller test statistic & -8.581258 & 0.0000 \\
Test critical values: & $1 \%$ level & -4.049586 & \\
& $5 \%$ level & -3.454032 & \\
$10 \%$ level & -3.152652 & \\
\hline
\end{tabular}

Null Hypothesis: LCIC has a unit root

Exogenous: Constant, Linear Trend

Lag Length: 4 (Automatic-based on AIC, maxlag = 4)

\begin{tabular}{cccc}
\hline & & $t$-Statistic & Prob. $^{*}$ \\
\hline Augmented Dickey-Fuller test statistic & -0.530218 & 0.9807 \\
Test critical values: & $1 \%$ level & -4.046072 & \\
& $5 \%$ level & -3.452358 & \\
& $10 \%$ level & -3.151673 & \\
\end{tabular}


Null Hypothesis: D (LCIC) has a unit root

Exogenous: Constant, Linear Trend

Lag Length: 3 (Automatic-based on AIC, maxlag = 4)

\begin{tabular}{cccc}
\hline & & $t$-Statistic & Prob. $^{*}$ \\
\hline Augmented Dickey-Fuller test statistic & -5.076255 & 0.0003 \\
Test critical values: & $1 \%$ level & -4.046072 & \\
& $5 \%$ level & -3.452358 & \\
$10 \%$ level & -3.151673 & \\
\hline
\end{tabular}

VEC Lag Order Selection Criteria

Endogenous variables: DLM2 DEXR DIFR DLCPS DLCIC

\begin{tabular}{ccccccc}
\hline Lag & LogL & LR & FPE & AIC & SC & HQ \\
\hline 0 & -204.4334 & NA & $9.50 \mathrm{e}-05$ & 4.927846 & $5.071531^{*}$ & $4.985640^{*}$ \\
1 & -168.1493 & $67.44584^{*}$ & $7.29 \mathrm{e}-05^{\star}$ & $4.662336^{*}$ & 5.524448 & 5.009102 \\
2 & -158.7894 & 16.29716 & 0.000106 & 5.030340 & 6.610879 & 5.666077 \\
3 & -136.6108 & 36.00767 & 0.000115 & 5.096725 & 7.395691 & 6.021433 \\
4 & -120.7281 & 23.91741 & 0.000147 & 5.311250 & 8.328643 & 6.524930 \\
5 & -106.6086 & 19.60127 & 0.000199 & 5.567261 & 9.303080 & 7.069912 \\
6 & -84.39132 & 28.22900 & 0.000229 & 5.632737 & 10.08698 & 7.424359 \\
7 & -69.83063 & 16.78761 & 0.000327 & 5.878368 & 11.05104 & 7.958962 \\
8 & -60.02281 & 10.15398 & 0.000544 & 6.235831 & 12.12693 & 8.605396 \\
\hline
\end{tabular}

${ }^{\star}$ Indicates lag order selected by the criterion, LR: sequential modified LR test statistic, FPE: Final prediction error, AIC: Akaike information criterion, SC: Schwarz information criterion, HQ: Hannan-Quinn information criterion (each test at $5 \%$ level).

ARDL Bounds Test

Sample: 8112

Included observations: 102

Null Hypothesis: No long-run relationships exist

$\begin{array}{ccc}\text { Test Statistic } & \text { Value } & \mathrm{k} \\ \text { F-statistic } & 6.703127 & 4\end{array}$

Critical Value Bounds

\begin{tabular}{ccc} 
Significance & I0 Bound & I1 Bound \\
$10 \%$ & 2.45 & 3.52 \\
$5 \%$ & 2.86 & 4.01 \\
$2.5 \%$ & 3.25 & 4.49 \\
$1 \%$ & 3.74 & 5.06 \\
\hline
\end{tabular}

Dependent Variable: LM2

Method: ARDL

Sample (adjusted): 8112

Included observations: 102 after adjustments

Maximum dependent lags: 4 (Automatic selection)

Model selection method: Akaike info criterion (AIC) 


\section{Continued}

Dynamic regressors (4 lags, automatic): EXR IFR LCPS LCIC

Fixed regressors: $\mathrm{C}$

Number of models evalulated: 2500

Selected Model: ARDL $(1,0,0,1,2)$

\begin{tabular}{|c|c|c|c|c|}
\hline Variable & Coefficient & Std. Error & $t$-Statistic & Prob.* \\
\hline $\operatorname{LM} 2(-1)$ & 0.747570 & 0.050388 & 14.83633 & 0.0000 \\
\hline EXR & $2.15 \mathrm{E}-05$ & $8.48 \mathrm{E}-05$ & 0.253197 & 0.8007 \\
\hline IFR & $7.72 \mathrm{E}-05$ & 0.000234 & 0.329780 & 0.7423 \\
\hline LCPS & 0.014123 & 0.037342 & 0.378192 & 0.7062 \\
\hline $\operatorname{LCPS}(-1)$ & 0.072220 & 0.037998 & 1.900637 & 0.0604 \\
\hline LCIC & 0.486424 & 0.029393 & 16.54884 & 0.0000 \\
\hline $\operatorname{LCIC}(-1)$ & -0.396912 & 0.044121 & -8.995953 & 0.0000 \\
\hline $\operatorname{LCIC}(-2)$ & 0.058052 & 0.031707 & 1.830917 & 0.0703 \\
\hline C & 0.339475 & 0.063813 & 5.319871 & 0.0000 \\
\hline R-squared & 0.999706 & \multicolumn{2}{|c|}{ Mean dependent var } & 8.009428 \\
\hline Adjusted R-squared & 0.999681 & \multicolumn{2}{|c|}{ S.D. dependent var } & 1.659916 \\
\hline S.E. of regression & 0.029649 & \multicolumn{2}{|c|}{ Akaike info criterion } & -4.114668 \\
\hline Sum squared resid & 0.081754 & \multicolumn{2}{|c|}{ Schwarz criterion } & -3.883053 \\
\hline Log likelihood & 218.8481 & \multicolumn{2}{|c|}{ Hannan-Quinn criter. } & -4.020879 \\
\hline F-statistic & 39559.51 & \multicolumn{2}{|c|}{ Durbin-Watson stat } & 1.668496 \\
\hline Prob (F-statistic) & 0.000000 & & & \\
\hline
\end{tabular}

ARDL Bounds Test

Sample: 7112

Included observations: 102

Null Hypothesis: No long-run relationships exist

\begin{tabular}{ccc}
\hline Test Statistic & Value & $\mathrm{k}$ \\
F-statistic & 0.912015 & 4 \\
& Critical Value Bounds & \\
Significance & I0 Bound & I1 Bound \\
$10 \%$ & 2.45 & 3.52 \\
$5 \%$ & 2.86 & 4.01 \\
$2.5 \%$ & 3.25 & 4.49 \\
$1 \%$ & 3.74 & 5.06 \\
\hline
\end{tabular}

Dependent Variable: EXR

Method: ARDL

Sample (adjusted): 7112

Included observations: 103 after adjustments

Maximum dependent lags: 4 (Automatic selection) 


\section{Continued}

Model selection method: Akaike info criterion (AIC)

Dynamic regressors (4 lags, automatic): LM2 IFR LCPS LCIC

Fixed regressors: $\mathrm{C}$

Number of models evalulated: 2500

Selected Model: ARDL $(2,0,0,0,0)$

\begin{tabular}{ccccc}
\hline Variable & Coefficient & Std. Error & $t$-Statistic & Prob. $^{*}$ \\
\hline EXR(-1) & 1.220624 & 0.098674 & 12.37024 & 0.0000 \\
EXR(-2) & -0.263069 & 0.101764 & -2.585102 & 0.0112 \\
LM2 & 14.65564 & 17.65140 & 0.830282 & 0.4084 \\
IFR & -0.002648 & 0.084270 & -0.031419 & 0.9750 \\
LCPS & -4.376877 & 8.822736 & -0.496091 & 0.6210 \\
LCIC & -7.374413 & 10.94607 & -0.673704 & 0.5021 \\
C & -24.29200 & 22.45592 & -1.081764 & 0.2821 \\
R-squared & 0.983669 & Mean dependent var & 126.6453 \\
Adjusted R-squared & 0.982649 & S.D. dependent var & 80.91200 \\
S.E. of regression & 10.65809 & Akaike info criterion & 7.636057 \\
Sum squared resid & 10905.10 & Schwarz criterion & 7.815116 \\
Log likelihood & -386.2569 & Hannan-Quinn criter. & 7.708582 \\
F-statistic & 963.7522 & Durbin-Watson stat & 1.977128 \\
Prob (F-statistic) & 0.000000 & & \\
\hline
\end{tabular}

ARDL Bounds Test

Sample: 7112

Included observations: 98

Null Hypothesis: No long-run relationships exist

\begin{tabular}{ccc}
\hline Test Statistic & Value & $\mathrm{k}$ \\
F-statistic & 0.808640 & 4 \\
& Critical Value Bounds & \\
Significance & I0 Bound & I1 Bound \\
$10 \%$ & 2.45 & 3.52 \\
$5 \%$ & 2.86 & 4.01 \\
$2.5 \%$ & 3.25 & 4.49 \\
$1 \%$ & 3.74 & 5.06 \\
\hline
\end{tabular}

Dependent Variable: IFR

Method: ARDI

Sample (adjusted): 7112 


\section{Continued}

Included observations: 99 after adjustments

Maximum dependent lags: 4 (Automatic selection)

Model selection method: Akaike info criterion (AIC)

Dynamic regressors (4 lags, automatic): LM2 EXR LCPS LCIC

Fixed regressors: $\mathrm{C}$

Number of models evalulated: 2500

Selected Model: ARDL $(4,0,0,0,0)$

\begin{tabular}{|c|c|c|c|c|}
\hline Variable & Coefficient & Std. Error & $t$-Statistic & Prob. ${ }^{*}$ \\
\hline $\operatorname{IFR}(-1)$ & 1.417559 & 0.102720 & 13.80028 & 0.0000 \\
\hline $\operatorname{IFR}(-2)$ & -0.188279 & 0.169971 & -1.107712 & 0.2709 \\
\hline $\operatorname{IFR}(-3)$ & -0.515586 & 0.169031 & -3.050238 & 0.0030 \\
\hline $\operatorname{IFR}(-4)$ & 0.221568 & 0.101433 & 2.184387 & 0.0315 \\
\hline LM2 & -0.550366 & 5.975196 & -0.092108 & 0.9268 \\
\hline EXR & 0.002088 & 0.009850 & 0.211978 & 0.8326 \\
\hline LCPS & 0.626236 & 2.952164 & 0.212128 & 0.8325 \\
\hline LCIC & -0.562863 & 3.688142 & -0.152614 & 0.8790 \\
\hline $\mathrm{C}$ & 4.293728 & 7.388747 & 0.581117 & 0.5626 \\
\hline R-squared & 0.965487 & \multicolumn{2}{|c|}{ Mean dependent var } & 19.59987 \\
\hline Adjusted R-squared & 0.962419 & \multicolumn{2}{|c|}{ S.D. dependent var } & 17.98814 \\
\hline S.E. of regression & 3.487157 & \multicolumn{2}{|c|}{ Akaike info criterion } & 5.422559 \\
\hline Sum squared resid & 1094.424 & \multicolumn{2}{|c|}{ Schwarz criterion } & 5.658479 \\
\hline Log likelihood & -259.4167 & \multicolumn{2}{|c|}{ Hannan-Quinn criter. } & 5.518012 \\
\hline F-statistic & 314.7109 & \multicolumn{2}{|c|}{ Durbin-Watson stat } & 2.045246 \\
\hline Prob (F-statistic) & 0.000000 & & & \\
\hline
\end{tabular}

ARDL Bounds Test

Sample: 10112

Included observations: 100

Null Hypothesis: No long-run relationships exist

\begin{tabular}{ccc}
\hline Test Statistic & Value & $\mathrm{k}$ \\
F-statistic & 5.081240 & 4 \\
& Critical Value Bounds & \\
Significance & I0 Bound & I1 Bound \\
$10 \%$ & 2.45 & 3.52 \\
$5 \%$ & 2.86 & 4.01 \\
$2.5 \%$ & 3.25 & 4.49 \\
$1 \%$ & 3.74 & 5.06 \\
\hline
\end{tabular}


Dependent Variable: LCPS

Method: ARDL

Sample (adjusted): 10112

Included observations: 100 after adjustments

Maximum dependent lags: 4 (Automatic selection)

Model selection method: Akaike info criterion (AIC)

Dynamic regressors (4 lags, automatic): LM2 EXR IFR LCIC

Fixed regressors: $\mathrm{C}$

Number of models evalulated: 2500

Selected Model: ARDL (3, 0, 0, 0, 0)

\begin{tabular}{ccccc}
\hline Variable & Coefficient & \multicolumn{1}{l}{ Std. Error } & $t$-Statistic & \multicolumn{1}{c}{ Prob. $^{*}$} \\
\hline LCPS(-1) & 0.643464 & 0.097837 & 6.576930 & 0.0000 \\
LCPS(-2) & 0.047433 & 0.116717 & 0.406393 & 0.6854 \\
LCPS(-3) & 0.089251 & 0.091219 & 0.978422 & 0.3304 \\
LM2 & 0.157173 & 0.158909 & 0.989073 & 0.3252 \\
EXR & -0.000616 & 0.000206 & -2.989560 & 0.0036 \\
IFR & 0.000534 & 0.000586 & 0.910665 & 0.3649 \\
LCIC & 0.103236 & 0.094456 & 1.092955 & 0.2773 \\
C & -0.150412 & 0.205849 & -0.730689 & 0.4668 \\
R-squared & 0.998352 & Mean dependent var & 7.857243 \\
Adjusted R-squared & 0.998227 & S.D. dependent var & 1.769851 \\
S.E. of regression & 0.074527 & Akaike info criterion & -2.278681 \\
Sum squared resid & 0.510999 & Schwarz criterion & -2.070268 \\
Log likelihood & 121.9341 & Hannan-Quinn criter. & -2.194333 \\
F-statistic & 7962.741 & Durbin-Watson stat & 2.225183 \\
Prob (F-statistic) & 0.000000 & r & \\
\hline & & & \\
\hline
\end{tabular}

ARDL Bounds Test

Sample: 8112

Included observations: 102

Null Hypothesis: No long-run relationships exist

\begin{tabular}{ccc}
\hline Test Statistic & Value & $\mathrm{k}$ \\
F-statistic & 4.841586 & 4 \\
& Critical Value Bounds & \\
Significance & I0 Bound & I1 Bound \\
$10 \%$ & 2.45 & 3.52 \\
$5 \%$ & 2.86 & 4.01 \\
$2.5 \%$ & 3.25 & 4.49 \\
$1 \%$ & 3.74 & 5.06 \\
\hline
\end{tabular}


Dependent Variable: LCIC

Method: ARDL

Sample (adjusted): 8112

Included observations: 102 after adjustments

Maximum dependent lags: 4 (Automatic selection)

Model selection method: Akaike info criterion (AIC)

Dynamic regressors (4 lags, automatic): LM2 EXR IFR LCPS

Fixed regressors: $\mathrm{C}$

Number of models evalulated: 2500

Selected Model: ARDL $(1,1,0,0,1)$

\begin{tabular}{cclcc}
\hline Variable & Coefficient & Std. Error & $t$-Statistic & Prob. $^{*}$ \\
\hline LCIC(-1) & 0.747832 & 0.054474 & 13.72824 & 0.0000 \\
LM2 & 1.517195 & 0.090371 & 16.78844 & 0.0000 \\
LM2(-1) & -1.117179 & 0.113923 & -9.806461 & 0.0000 \\
EXR & $1.15 \mathrm{E}-06$ & 0.000149 & 0.007692 & 0.9939 \\
IFR & -0.000441 & 0.000412 & -1.072427 & 0.2863 \\
LCPS & 0.014290 & 0.066018 & 0.216457 & 0.8291 \\
LCPS(-1) & -0.139491 & 0.067168 & -2.076745 & 0.0406 \\
C & -0.481515 & 0.118018 & -4.080021 & 0.0001 \\
R-squared & 0.999146 & Mean dependent var & 6.992431 \\
Adjusted R-squared & 0.999082 & S.D. dependent var & 1.736022 \\
S.E. of regression & 0.052592 & Akaike info criterion & -2.977324 \\
Sum squared resid & 0.259995 & Schwarz criterion & -2.771444 \\
Log likelihood & 159.8435 & Hannan-Quinn criter. & -2.893956 \\
F-statistic & 15708.14 & Durbin-Watson stat & 1.697695 \\
Prob (F-statistic) & 0.000000 & r & \\
\hline
\end{tabular}

Vector Error Correction Estimates

Sample (adjusted): 9112

Included observations: 99 after adjustments

Standard errors in ( ) \& $t$-statistics in []

\begin{tabular}{cc}
\hline Cointegrating Eq: & CointEq1 \\
\hline $\operatorname{LM} 2(-1)$ & 1.000000 \\
$\operatorname{EXR}(-1)$ & -0.000113 \\
& $(0.00034)$ \\
& {$[-0.32737]$} \\
& -0.001102 \\
$\operatorname{IFR}(-1)$ & $(0.00100)$ \\
& {$[-1.10643]$} \\
\hline
\end{tabular}




\section{Continued}

\begin{tabular}{|c|c|c|c|c|c|}
\hline \multirow[t]{3}{*}{$\operatorname{LCPS}(-1)$} & -0.311468 & & & & \\
\hline & $(0.06352)$ & & & & \\
\hline & [-4.90327] & & & & \\
\hline \multirow[t]{3}{*}{$\operatorname{LCIC}(-1)$} & -0.621778 & & & & \\
\hline & $(0.07217)$ & & & & \\
\hline & {$[-8.61579]$} & & & & \\
\hline $\mathrm{C}$ & -1.196502 & & & & \\
\hline Error Correction: & $\mathrm{D}(\mathrm{LM} 2)$ & $\mathrm{D}(\mathrm{EXR})$ & $\mathrm{D}$ (IFR) & D(LCPS) & $\mathrm{D}(\mathrm{LCIC})$ \\
\hline \multirow[t]{3}{*}{ CointEq1 } & -0.168001 & 29.26148 & 7.004815 & -0.032957 & 0.097993 \\
\hline & $(0.09862)$ & $(18.3111)$ & $(6.25559)$ & $(0.15080)$ & $(0.17664)$ \\
\hline & {$[-1.70354]$} & [1.59802] & [1.11977] & {$[-0.21855]$} & {$[0.55475]$} \\
\hline \multirow[t]{3}{*}{$\mathrm{D}(\operatorname{LM} 2(-1))$} & 0.308855 & 16.46215 & 7.030901 & 0.473076 & 0.388552 \\
\hline & $(0.18265)$ & $(33.9143)$ & $(11.5861)$ & $(0.27930)$ & $(0.32717)$ \\
\hline & [1.69093] & {$[0.48540]$} & {$[0.60684]$} & [1.69380] & [1.18762] \\
\hline \multirow[t]{3}{*}{$\mathrm{D}(\operatorname{EXR}(-1))$} & $-9.71 \mathrm{E}-05$ & 0.235130 & -0.000295 & -0.000389 & -0.000256 \\
\hline & $(0.00054)$ & $(0.10104)$ & $(0.03452)$ & $(0.00083)$ & $(0.00097)$ \\
\hline & {$[-0.17841]$} & [2.32717] & {$[-0.00853]$} & {$[-0.46719]$} & {$[-0.26308]$} \\
\hline \multirow[t]{3}{*}{$\mathrm{D}(\operatorname{IFR}(-1))$} & -0.000698 & 0.300454 & 0.455950 & 0.000757 & -0.000895 \\
\hline & $(0.00144)$ & $(0.26801)$ & $(0.09156)$ & $(0.00221)$ & $(0.00259)$ \\
\hline & {$[-0.48351]$} & [1.12105] & [4.97976] & {$[0.34278]$} & {$[-0.34617]$} \\
\hline \multirow[t]{3}{*}{$\mathrm{D}(\operatorname{LCPS}(-1))$} & 0.101315 & 14.36538 & 2.788954 & -0.090789 & 0.165318 \\
\hline & $(0.07416)$ & $(13.7701)$ & $(4.70428)$ & $(0.11340)$ & $(0.13284)$ \\
\hline & [1.36613] & [1.04323] & [0.59285] & {$[-0.80058]$} & [1.24450] \\
\hline \multirow[t]{3}{*}{$\mathrm{D}(\operatorname{LCIC}(-1))$} & -0.321199 & -17.22164 & 1.222886 & -0.198273 & -0.416171 \\
\hline & $(0.11086)$ & $(20.5843)$ & (7.03219) & $(0.16952)$ & $(0.19857)$ \\
\hline & [-2.89729] & {$[-0.83664]$} & [0.17390] & {$[-1.16961]$} & {$[-2.09579]$} \\
\hline \multirow[t]{3}{*}{$\mathrm{C}$} & 0.043803 & 1.479145 & -0.842567 & 0.042472 & 0.043393 \\
\hline & $(0.00896)$ & $(1.66457)$ & $(0.56867)$ & $(0.01371)$ & $(0.01606)$ \\
\hline & [4.88597] & {$[0.88861]$} & {$[-1.48166]$} & [3.09821] & [2.70230] \\
\hline R-squared & 0.158969 & 0.113110 & 0.244882 & 0.043725 & 0.078389 \\
\hline Adj. R-squared & 0.104119 & 0.055269 & 0.195635 & -0.018641 & 0.018284 \\
\hline Sum sq. resids & 0.306563 & 10568.86 & 1233.496 & 0.716807 & 0.983565 \\
\hline S.E. equation & 0.057725 & 10.71816 & 3.661634 & 0.088269 & 0.103397 \\
\hline F-statistic & 2.898262 & 1.955539 & 4.972549 & 0.701098 & 1.304199 \\
\hline Log likelihood & 145.5089 & -371.6670 & -265.3381 & 103.4645 & 87.80379 \\
\hline Akaike AIC & -2.798159 & 7.649839 & 5.501779 & -1.948777 & -1.632400 \\
\hline Schwarz SC & -2.614666 & 7.833332 & 5.685272 & -1.765284 & -1.448906 \\
\hline Mean dependent & 0.049326 & 2.772241 & -0.479259 & 0.050031 & 0.051413 \\
\hline S.D. dependent & 0.060988 & 11.02722 & 4.082709 & 0.087457 & 0.104355 \\
\hline
\end{tabular}




\section{Continued}

Determinant resid covariance (dof adj.) 9.93E-05

Determinant resid covariance $\quad 6.88 \mathrm{E}-05$

Log likelihood $\quad-227.9596$

Akaike information criterion $\quad 5.413326$

Schwarz criterion

6.461859
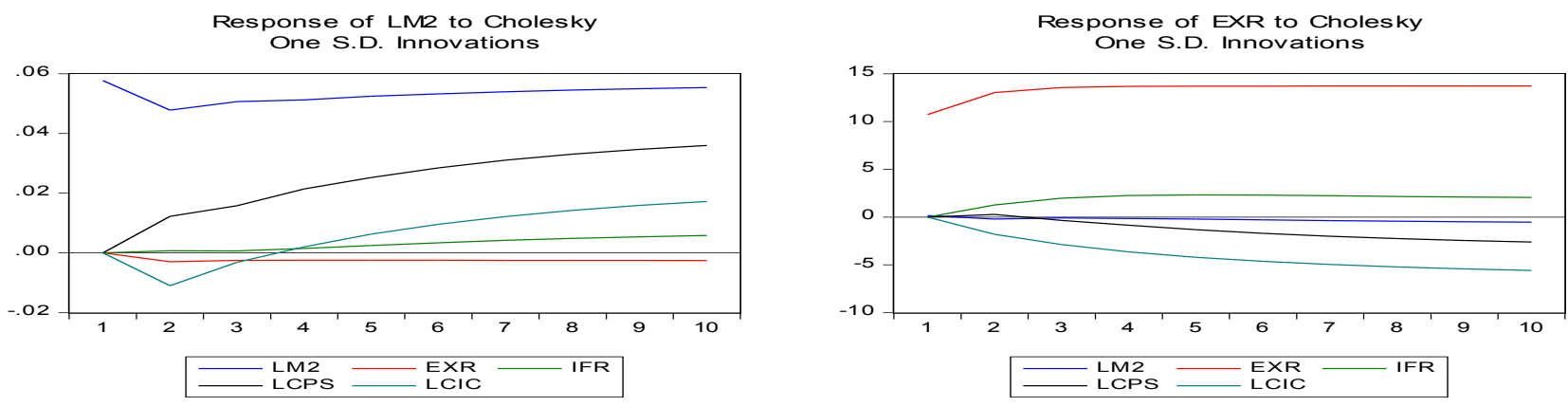

Response of IFR to Cholesky One S.D. Innovations

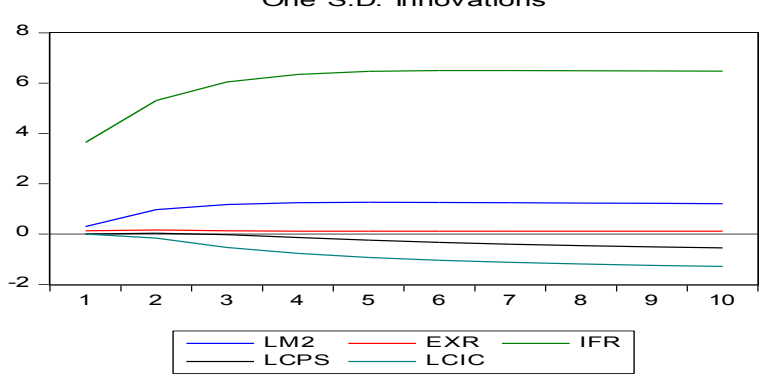

Response of LCPS to Cholesky One S.D. Innovations

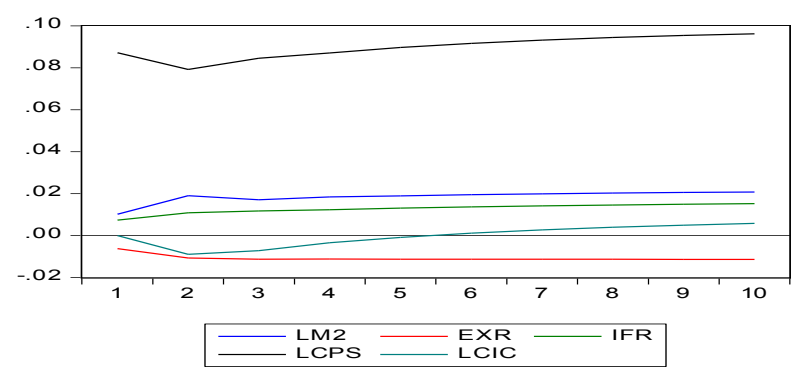

Response of LCIC to Cholesky

One S.D. Innovations

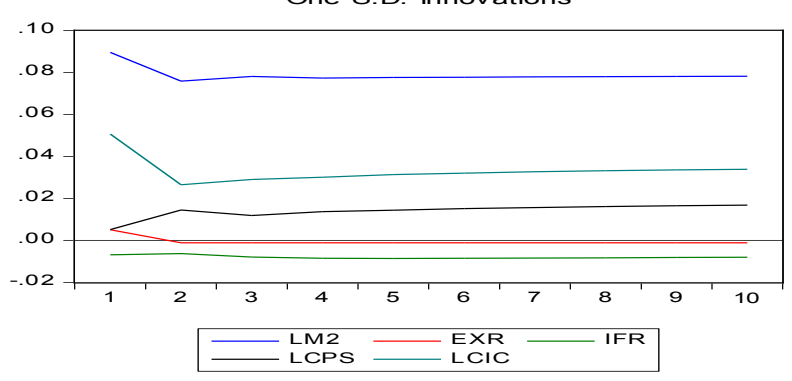

